\title{
Tourmalinisation in peraluminous granitic context: from experiment to thermodynamic modelling.
}

\author{
JULIEN FORT ${ }^{1}$, STANISLAS SIZARET ${ }^{1}$, MICHEL \\ PICHAVANT $^{1}$, ARNAULT LASSIN $^{2}$, PHILIPPE BLANC ${ }^{2}$, \\ JOHANN TUDURI ${ }^{1,2}$ AND OLIVIER BLEIN ${ }^{2}$ \\ ${ }^{1}$ Institut des Sciences de la Terre d'Orléans \\ ${ }^{2}$ BRGM
}

Presenting Author: julien.fort@univ-orleans.fr

Tourmaline $\left(\mathrm{XY}_{3} \mathrm{Z}_{6}\left[\mathrm{~T}_{6} \mathrm{O}_{18}\right]\left[\mathrm{BO}_{3}\right]_{3} \mathrm{~V}_{3} \mathrm{~W}\right)$ records the physico chemical conditions during its crystallisation. As its primary chemical zoning are generally unbalanced, its occurrence as an alteration product may be therefore used to decipher the physicochemical properties of mineralising fluids. However, the role of the tourmalinisation in hydrothermal processes remains little studied, if not poorly understood. The complexity of its thermodynamic properties is related to the presence of four cationic sites ( $\mathrm{X}, \mathrm{Y}, \mathrm{Z}$ and $\mathrm{T})$ allowing the accommodation of a wide variety of elements [1]. Moreover, the phenomena of deprotonation, $\mathrm{Si}^{\mathrm{IV}} \mathrm{B}$ and valence state, make the approach of solid solution properties complex [2]. Thus, thermodynamic properties are most often estimated [3,4] and only a few measurements have been carried out on a reduced number of near-endmembers crystals $[5,6]$.

This study aims to investigate the stability field of the schorl $(\mathrm{Na}-\mathrm{Fe})$ - dravite $(\mathrm{Na}-\mathrm{Mg})$ solid solution using experimentation at $200 \mathrm{MPa}$ total pressure between $400^{\circ}$ and $600^{\circ} \mathrm{C}$ as a function of the boron content of the fluid and $\mathrm{fO} 2$ condition, using an internally heated gas apparatus. Those metasomatic experiments have been conducted on a mixture of natural crystals of cordierite + albite, representing a peraluminous granite composition in a Na-Mg-Fe-Al-Si-B-O-H system, characterised by a high-Mg and low-Fe content. These experiments were performed in order to simulate a classic aluminous host of these tourmaline alterations in granitic context.

The chemistry of the fibrous dravite - Mg-foitite $\left([]_{\mathrm{X}}-\mathrm{Mg}\right)$ crystallised varies due to alkali-deficient and proton-deficient substitutions, depending of the system conditions. Their stability varies from $4 \mathrm{wt} \% \mathrm{~B}_{2} \mathrm{O}_{3}$ at $600^{\circ} \mathrm{C}$ to $3 \mathrm{wt} \% \mathrm{~B}_{2} \mathrm{O}_{3}$ at $400^{\circ} \mathrm{C}$, which is far higher than the few ppm required to produce tourmaline in thermochemical models. Hence the objective is to use those experimental results to characterize, in a $\mathrm{P}, \mathrm{T}, \mathrm{W} / \mathrm{R}$ space, the tourmalinisation process in terms of alteration sequence and porosity variation.

References:

[1] Henry \& Dutrow (2018), Jour.Geosci.63, 77-98.

[2] Henry et al. (2011), Am.Min.96, 895-913.

[3] Garofalo et al. (2000), Am.Min.85, 78-88.

[4] Hinsberg \& Schumacher (2007), J.Metamorph.Geol.25, 769-779.

[5] Kuyunko et al. (1984), Geokhimíya.10, 1458-1465.

[6] Ogoradova et al. (2012), Thermochim.Acta.539, 1-6. 